\title{
IMPLEMENTATION OF 6R STRATEGY IN FDM PRINTING PROCESS: CASE - SMALL ELECTRONIC ENCLOSURE BOX
}

Paper received: 27.10.2020; Paper accepted: 03.12.2020.

This paper provides an algorithm for the application of additive manufacturing in the sustainable development of the enterprise. The manufacturing process includes the process of manufacturing preparation, the process of realization of manufacturing (or remanufacturing), the end of the manufacturing process with additional processing and recycling process. A $6 R$ strategy in the realization of new or redesign of existing elements/parts has been implemented. Additive manufacturing or FDM printing technology enables frequent and simple modification of the model at a customer's request, and prior to the model enters the manufacturing itself. The starting material for making the model was polylactic acid (PLA). This paper aims to present the procedure of the realization of an electronics enclosure for a miniature pressure transmitter on a 3D printer. This gives the designer the opportunity to correct existing errors, modify the product according to the requirements of end-users, or to design a completely new product (prototype). In order for the algorithm to get the right confirmation, it is important to design a product that enables: accessibility, easy interchangeability, disassembly, the possibility of finishing and reuse.

Keywords: Algorithm; Sustainable Development; 6R; Additive manufacturing; Electronic enclosure box.

\section{INTRODUCTION}

The short product life cycle and the increasing complexity of the product are becoming the main imperative in the sustainable development of the company. That is why companies need to increase their innovative activities and shorten the time to enter markets, and that brings with it a new manufacturing technology - Additive Technology (AT).

When making a model/prototype, its geometry is first considered, and then it is examined how the complexity of the product can improve the company's position. The implementation of AT creates additional value in the realization of complex geometry, which is not easy to realize with conventional processing. When it comes to sustainable business growth, the implementation of AT implies: improving the use of resources, implementing more effective manufacturing methods, applying new manufacturing processes, applying new materials, and adopting new business models (Despeisse, \& Ford, 2015).

The application of additive manufacturing (AM) produces waste that is negligible compared to conventional manufacturing (CM) (Wang, Zanni, $\&$ Kobbelt, 2016). AM works on the principle of adding materials in layers (Ciubară et al., 2018), and the obtained waste mainly includes imperfect or unfinished models (Peng, \& Sun, 2017). AM 
M. Vorkapić Implementation of 6R strategy in FDM printing process:

et al. Case - small electronic enclosure box

technology effects on reducing weight, use of water, energy, and material, all of which have a positive impact on sustainability. $\mathrm{CM}$ creates material waste or absorbs extra material, while AM uses less toxic materials, additives, and cutting fluids.

By implementing AM, designers are granted greater freedom to design and define optimal product design (Brackett, Ashcroft, \& Hague, 2011). It is possible to create a product with different materials that have different mechanical properties to satisfy different specifications at different locations within the model (Sossou, Demoly, Montavon, \& Gomes, 2018).

\section{Functional product analysis}

Functional product analysis (Sossou et al., 2018) considers the design of the product to be an input of the process. In this context, three important steps in the product analysis are highlighted: 1) external appearance (the relation between the product and the environment is required);2) the principle of disassembly (the breakdown of the product by logical sequence is considered) and 3) the product architecture; (components and their connections with the elements of the assembly itself, as well as with independent design elements are analyzed).

Product design can be re-created using any 3D CAD software package based on existing documentation or using advanced tools/software that take over the configuration of the model itself. Here, customers have a major role to play in determining the concept, while AM is an auxiliary tool for very quick product realization. It is necessary to consider the following activities (Eyers, \& Potter, 2017) before embarking on the implementation of the design: 1) preparatory activities (pre-processing), 2) manufacturing and 3) additional or final processing. Some of the key design factors to be kept in mind when designing AM include: closed gaps, surface treatment, strength, and flexibility, as well as materials and equipment costs (Diegel, Singamneni, Reay, \& Withell, 2010).

\section{FDM printing and materials}

AM are made of plastic parts, but other materials such as metal, ceramics, and various composites can be used (Nannan, 2013).
FDM systems use a number of thermoplastics. The benefits of using FDM printing are reduction of the unnecessary use of materials, shortening the time for design and development of usable elements, manufacturing of components with complex geometry, use of new materials with good characteristics, and reducing the amount of realized parts/elements. (Wang, Zanni, \& Kobbelt, 2016).

There are several drawbacks in the use of FDM printers: line visibility on the surface of the model, very low strength after making the piece, the need for further processing and the need to manufacture a supporting structure, long realization time, and quite expensive material (Galantucci, Lavecchia, \& Percoco, 2009).

Non-toxic thermoplastic materials such as PLA and ABS are primarily used in FDM printing. These materials have a low melting point, lower noise levels during building, and need less energy when heating the nozzle and the working surface (Peng, \& Sun, 2017).

PLA (Polylactic Acid) is a biodegradable, thermoplastic material and is extracted $100 \%$ from sustainable sources such as beets, potatoes, and maize (Jordá-Vilaplana et al., 2014). PLA does not release harmful gasses into the atmosphere (King, Babasola, Rozario, \& Pearce, 2014).

ABS (Acrylonitrile Butadiene Styrene) is a polymer of excellent mechanical properties, hightemperature tolerance, and impact of resistance (Lim et al., 2010). Vapors emitted during the melting of ABS are hazardous to human health and the environment as a whole, hence it is important to provide filtration and an isolated (closed) system of work with as little human presence as possible (Stephens, Azimi, El Orch, \& Ramos, 2013).

\section{FDM printing technology}

The methodology of model/prototype development using the FDM method takes place in the following steps (Zivanovic et al., 2020):

1. The process starts with the 3D CAD model. The model is realized using one of the CAD software packages.

2. The 3D model is imported as *.stl file into a specialized program (eg. open source Ultimaker Cura), which adjusts the operating parameters of the system. The STL file is a standard format for 3D printing and provides good readability in 
many 3D programs (Wong, \& Hernandez, 2012). Disadvantages in manipulation with * stl. files are reflected in the fact that there is a loss of the desired printer resolution, which mainly refers to the thickness of each layer.

3. After appropriate settings and print simulation, a $G$ code is generated in the *.gcod extension that the $3 \mathrm{D}$ printer recognizes. The $\mathrm{G}$ code is a standard format that describes the tool path (injectors in the FDM procedure). The described steps are partially automated, but this last step requires an operator.
4. In the end, the 3D model is realized, and after manufacturing, the excess material is removed and the model is cleaned and further processed (Zeltmann et al., 2016).

Therefore, the application of FDM printing requires advanced technical knowledge in the preparation, setting parameters, and the process of making a model/prototype (Cupar, Pogačar, \& Stjepanovič, 2015). The block diagram where the $3 \mathrm{D}$ model is transformed into a finished model/prototype (Junk, \& Schröder, 2016) is shown in Figure 1.

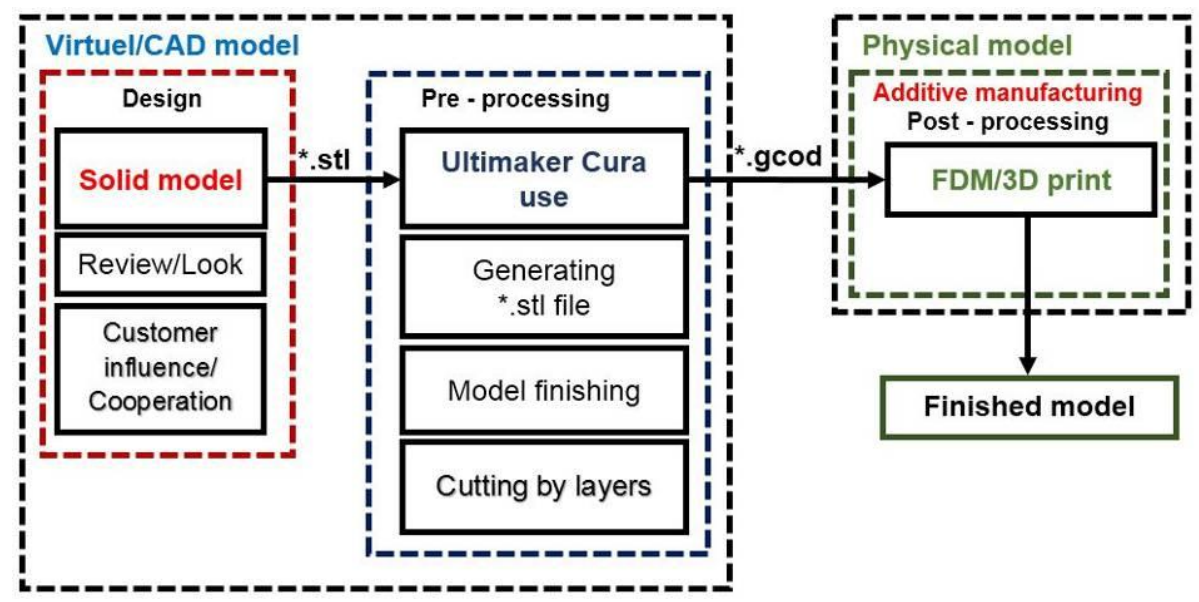

Figure 1: Block diagram of model/prototype realization

\section{R strategy}

The 6R strategy is important for the sustainable development of the company, which includes: 1.) the reduction of waste to a minimum; 2.) the reuse of waste or used product; 3 .) the processing of waste for the purposes of environmental protection - recycling; 4.) the regeneration of raw products, materials, and resources from waste that cannot be reduced, reused or recycled - recovered; 5) the redesign of a product, business area, or complete business process (Van Ackere, Larsen, \& Morecroft 1993), and 6) remanufacturing which includes disassembly, cleaning, measuring and testing of parts, as well as disposal of correct/repaired parts in the warehouse (Sarkis, 2001).

Product redesign is divided into parametric and adaptive redesigns (Otto, \& Wood, 1998). Parametric redesign involves the basic product model or the latest product configuration model after redesign (changes in geometry, materials, minor changes in the product). Many of these improvements are determined by consumers. The adaptive redesign allows designers the ability to come up with appropriate solutions for product assemblies and subassemblies. The aim of recycling is to reuse the material or elements of the used product. In general, the product can be made up of old and new components. The material cost of replication is just $40 \%$ of the overall cost compared to $70 \%$ of the total cost of development of new goods (Hindo, \& Arndt 2006). However, designers are increasingly wary of recycled materials, as these components may have variable quality characteristics (Barker, \& King, 2006).

According to Gehin, Zwolinski, and Brissaud (2008), the following advantages of remanufacturing are emphasized: 1) companies which use recycled goods minimize their costs; 2) the application of remanufacturing in marketing terms is the basis for increasing profits; 3 ) the remanufacturing process uses specialized equipment; 4) optimizing tools due to disassembly and assembly; 5) the remanufacturing provides stability in investment (6) suppliers are independent. 


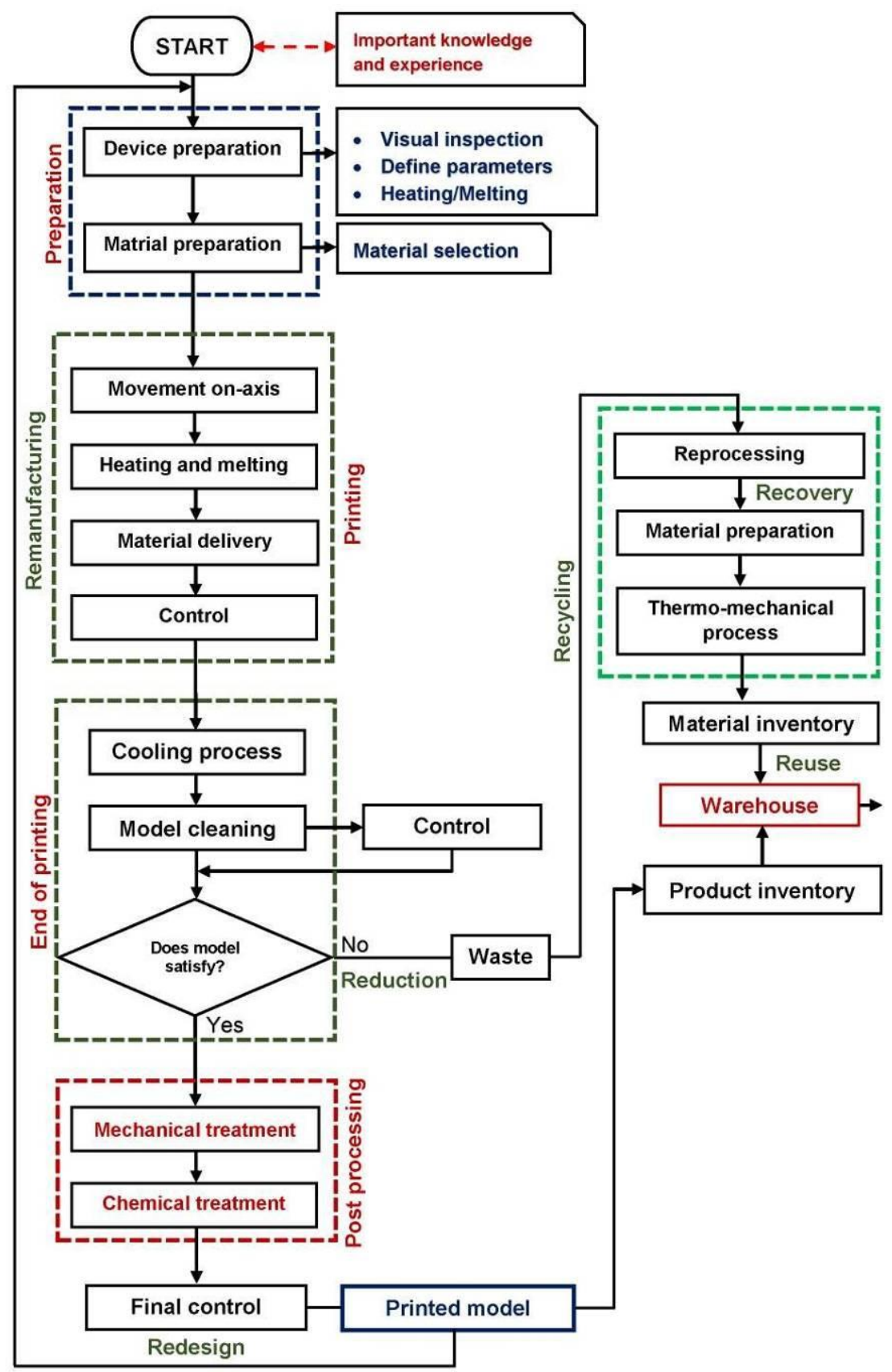

Figure 2: Algorithm for AM application in sustainable enterprise development

\section{METHODOLOGY}

The goal of this paper is to illustrate the value of the 6R strategy for the sustainable development of companies. As a solution, an algorithm for the 6R strategy implementation for sustainable development of the organization is used by AM for the implementation of new or updated existing elements/parts (Maxwell, \& Van der Vorst, 2003). The algorithm with the implementation of AM (Cafolla, Ceccarelli, Wang, \& Carbone, 2016; Sanchez, Boudaoud, Hoppe, \& Camargo, 2017) involves the manufacturing preparation process, the manufacturing (or remanufacturing) process, the completion of the manufacturing process with the subsequent processing and recycling process, see Figure 2.

Remanufacturing potentially helps many developing economies. Product reuse and recycling are becoming more intensive, though processed/modified or repaired goods are cheaper than newly produced products (Matsumoto, Yang, Martinsen, \& Kainuma, 2016). The algorithm 
ensures that such pieces are reused without any previous renovation or finishing. In order to confirm the algorithm correctly, it is necessary to design a product that allows: usability, easy replacement of parts/assemblies, disassembly of assemblies, the possibility of finishing, and reuse.

Before starting FDM printing, the parameters are specified first and the material is selected. By placing the system into operation, the printing is permanently controlled by the operator. At the end of the manufacturing process, additional geometry and surface control is carried out during the execution of the model. The approved model is further refined mechanically and/or chemically, see Fig. 2.

Check for errors in the preparation should only affect the layer and should not be spread to other layers. However, a change in the speed of the injector or an initial error in the system positioning can cause irregularities affecting the overall error (Oropallo, \& Piegl, 2016). Input errors in the preparation of the output often emerge from the selection of printing materials whose characteristics affect the efficiency of the printing process. Set parameters during 3D printing have a major effect on the surface roughness of the produced pieces. Such parts typically have a high surface roughness and need additional surface treatment to achieve smooth surfaces (Qattawi, \& Ablat, 2017).

All this is acceptable if the model meets the mentioned criteria, but if it does not meet, it is disposed as waste. In the algorithm, waste is not seen as a permanently lost material, but as a resource that can be recycled and reused. Recycled material is later disposed of in a material/semifinished product warehouse.

\section{EXPERIMENTAL WORK}

The example of the 6R algorithm use in the sustainable development of the enterprise is the realization of a small electronics enclosure for a pressure transmitter. It is about a domestic manufacturer of sensors and electronic pressure transducers, level, and temperature transmitters in Serbia, IHTM-CMT. The realized electronics enclosure using AM is shown in Figure 3.

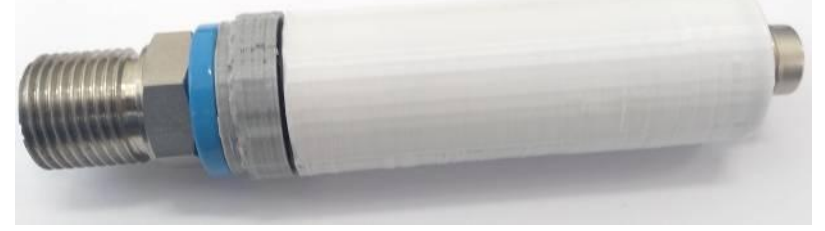

Figure 3: Small electronics enclosure for the pressure transmitter

The shown product is of modular architecture, consisting of the following modules: 1) pressure transducer, 2) electronics enclosure, and 3) electronics block. According to Urlich and Tung (1991), the modular product is reflected in 1) economic volume of components, 2) fast finishing of products, 3) increased product variety, 4) reduced-order time, 5) simplified design, and testing.

The electronics enclosure is made based on the existing technical documentation. In this stage, it is possible to correct existing errors in design and modify the enclosure according to the requirements of end-users. A 3D representation of the elements of the electronics box made based on 2D documentation is shown in Figure 4. PLA material was used to make the enclosure.

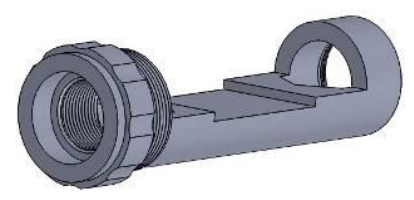

a)

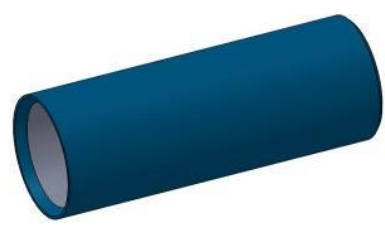

b)
Figure 4: Elements of electronics box: a) electronics carrier, b) cover

In this paper, a Wanhao Duplicator 3D printer, type i3 plus, manufactured by the People's Republic of China, was used to describe and implement the algorithm, see Figure 5. PLA filament, $1.75 \mathrm{~mm}$ in diameter (manufacturer Wanhao) was used for the model realization.

The sample was printed with defined temperatures and speeds, and they are: 1) $215{ }^{\circ} \mathrm{C}$ for the nozzle (printing temperature), 2) $60{ }^{\circ} \mathrm{C}$ for the plate (plate temperature), 3) $50 \mathrm{~mm} / \mathrm{s}$ print speed, 4) $70 \mathrm{~mm} / \mathrm{s}$ travel speed of the nozzle at idle (travel speed) and 5) $+45 /-45$, infill orientation .

An illustration of the realized elements of the electronics enclosure, on a 3D printer, is shown in Figure 6. 


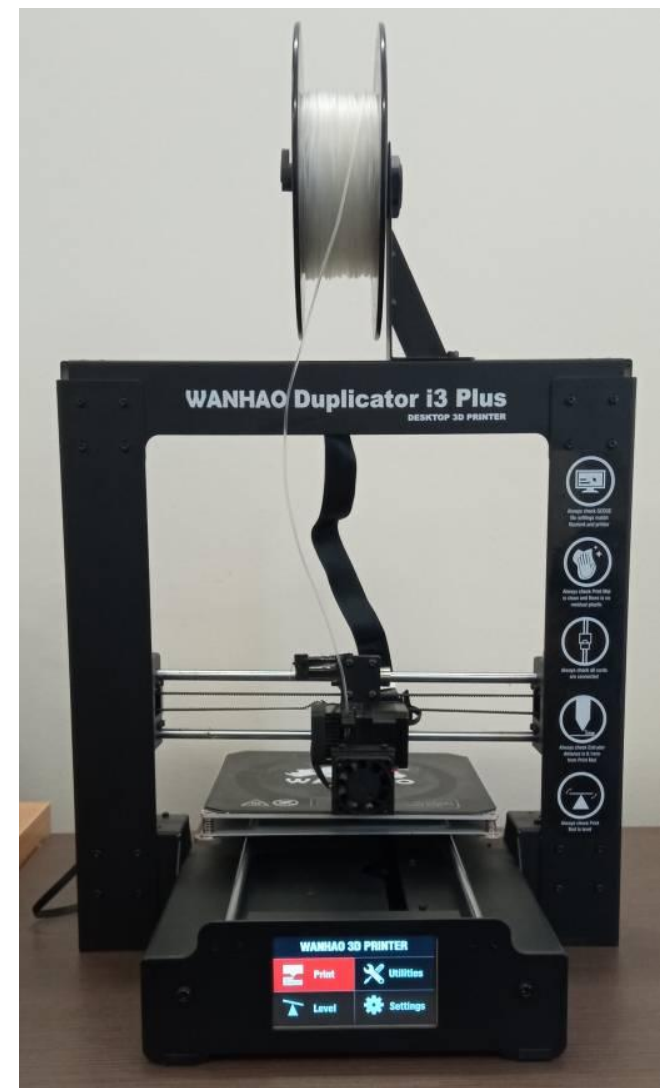

Figure 5: 3D printer

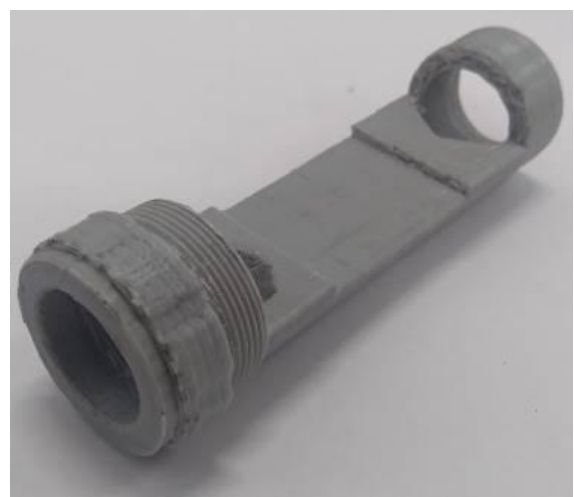

a)

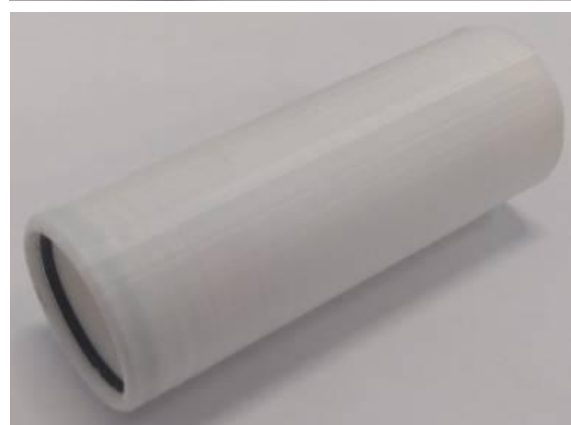

Figure 6: Electronics enclosure elements made on a $3 D$ printer

Many irregularities can be seen in the pictures. This model cannot be used immediately, but it is necessary to perform additional surface machining. Methods of machine additional processing include manual grinding of parts, traditional machining, and finishing polishing, while chemical processing methods include painting, coating, heating, and processing with some chemical agent.

In order to save on plastic, 3D printed parts are made to have a solid shell that surrounds the porous (partially hollow) interior. For obtaining better mechanical properties, there is a need for chemical or thermal processing.

Using AM does not give the desired accuracy in the dimensions of the product, so sometimes it is necessary to machine (using $\mathrm{CM}$ ) to certain tolerances, see Figure 7.

Mechanical processing of the samples was performed with the help of four sandpapers of different granulations (P100, P180, P320, P400) with constant water cooling in order to prevent heating and melting of plastic parts.

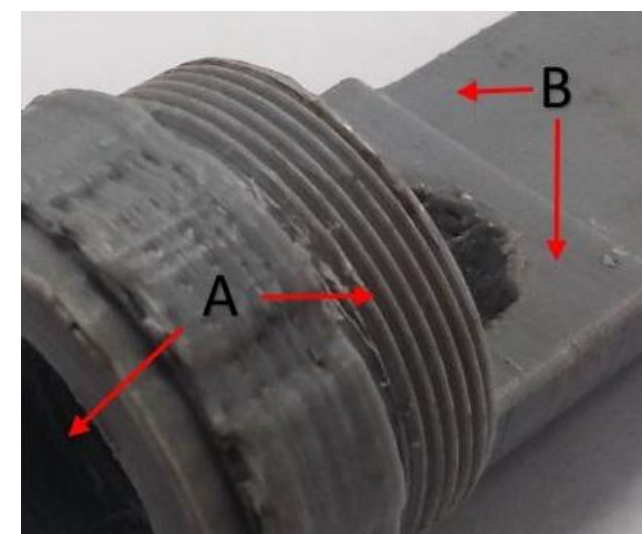

Figure 7: Additional machining on the lathe: thread (A) and contact surface (B)

Following was used in the process of mechanical processing: cooling water; compressed air for cleaning and drying surfaces; fine grinding and polishing apparatus, as well as a device for dimensional control before and after processing. The methodology of additional surface treatment and finalization of the model is shown in Table 1.

The process of manual polishing significantly affects the increase in the quality of treated surfaces, but can also lead to a reduction in the designed dimensions. The process of gritting and polishing the electronics enclosure is shown in Figure 8. 
M. Vorkapić Implementation of 6R strategy in FDM printing process:

Table 1: The methodology of additional processing of electronics enclosure

\begin{tabular}{|c|c|c|c|c|c|c|}
\hline$\frac{0}{\Delta}$ & 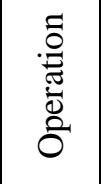 & Procedure & 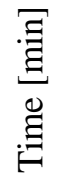 & 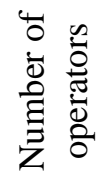 & Risk & Remark \\
\hline 1 & 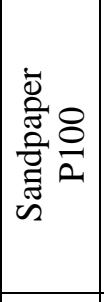 & $\begin{array}{l}\text { Operators process and control the } \\
\text { pieces. At certain positions, grinding } \\
\text { equipment is also used to remove } \\
\text { large irregularities. The dimensions } \\
\text { of the piece are checked. } \\
\text { Supplementary material is removed } \\
\text { mechanically. }\end{array}$ & 40 & 2 & $\begin{array}{l}\text { Separation of the } \\
\text { layers may occur } \\
\text { due to the rapid } \\
\text { removal of } \\
\text { additional } \\
\text { material. }\end{array}$ & $\begin{array}{l}\text { There is a large } \\
\text { decline due to the } \\
\text { removal of } \\
\text { additional material. }\end{array}$ \\
\hline 2 & 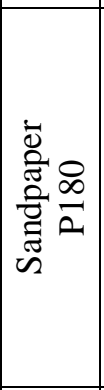 & $\begin{array}{l}\text { Mechanical processing is performed } \\
\text { by uniform pressure on the surfaces } \\
\text { with continuous water cooling. } \\
\text { Irregularities on curves, grooves, } \\
\text { openings, and threads have been } \\
\text { eliminated here. The goal is to } \\
\text { reduce the dimensions to as accurate } \\
\text { a measure as possible. The pieces are } \\
\text { cleaned with compressed air. }\end{array}$ & 25 & 2 & $\begin{array}{l}\text { Impossibility to } \\
\text { remove material } \\
\text { in holes, } \\
\text { channels, and } \\
\text { grooves. }\end{array}$ & $\begin{array}{l}\text { There is a smaller } \\
\text { waste after } \\
\text { processing holes, } \\
\text { curves, grooves. }\end{array}$ \\
\hline 3 & 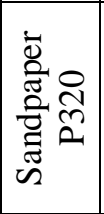 & $\begin{array}{l}\text { All surfaces are still treated, to } \\
\text { minimize deviations from the desired } \\
\text { parameters. }\end{array}$ & 20 & 2 & I & $\begin{array}{l}\text { There is waste in } \\
\text { the form of fine } \\
\text { dust. Occupational } \\
\text { safety measures are } \\
\text { needed. }\end{array}$ \\
\hline 4 & 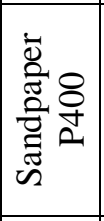 & $\begin{array}{l}\text { Smooth surfaces are obtained. It is a } \\
\text { preparatory process by which the } \\
\text { surfaces are coated with a thin layer } \\
\text { of putty. }\end{array}$ & 15 & 1 & I & $\begin{array}{l}\text { There is waste in } \\
\text { the form of fine } \\
\text { dust. Occupational } \\
\text { safety measures are } \\
\text { needed. }\end{array}$ \\
\hline 5 & 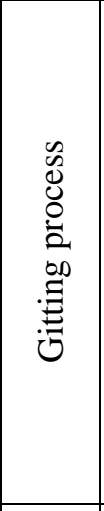 & $\begin{array}{l}\text { After the putty has been applied and } \\
\text { dried, polishing with P1000 } \\
\text { sandpaper, smooth surfaces prepared } \\
\text { for painting are obtained. }\end{array}$ & & & $\begin{array}{l}\text { Applying putty } \\
\text { paste is applied } \\
\text { too much, the } \\
\text { processing time } \\
\text { is increased and } \\
\text { the contour of } \\
\text { the model is } \\
\text { changed. }\end{array}$ & $\begin{array}{l}\text { The paste is } \\
\text { applied in as small } \\
\text { a layer as possible } \\
\text { to correct any } \\
\text { remaining } \\
\text { irregularities. Fine } \\
\text { powder occurs } \\
\text { after polishing } \\
\text { surfaces. } \\
\text { Occupational } \\
\text { safety measures are } \\
\text { needed. }\end{array}$ \\
\hline 6 & 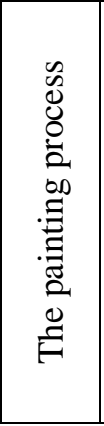 & $\begin{array}{l}\text { The final procedure gives the color } \\
\text { and final appearance of the } \\
\text { element/prototype. Measures are } \\
\text { being controlled. }\end{array}$ & & & $\begin{array}{l}\text { Surface quality } \\
\text { and appearance } \\
\text { of irregularities } \\
\text { after painting. }\end{array}$ & $\begin{array}{l}\text { The final } \\
\text { measurements are } \\
\text { checked, the } \\
\text { model/prototype is } \\
\text { cleaned with } \\
\text { compressed air and } \\
\text { then painted. } \\
\text { Occupational } \\
\text { safety measures are } \\
\text { needed. }\end{array}$ \\
\hline
\end{tabular}




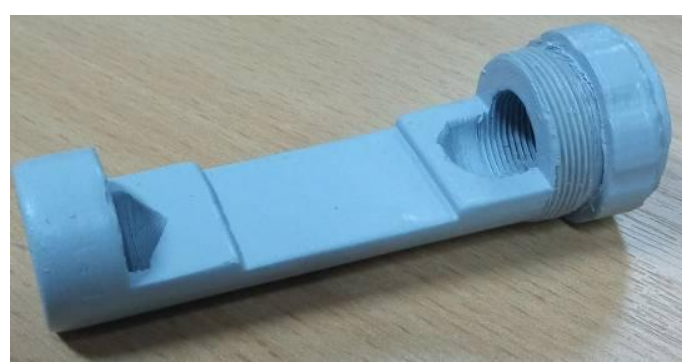

a)

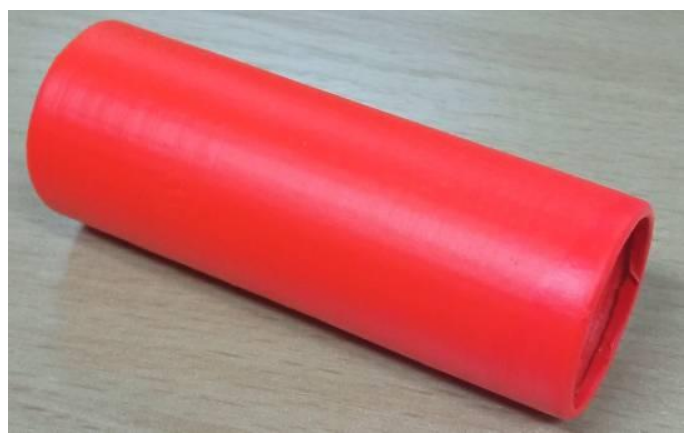

Figure 8: Additional mechanical processinggritting and final polishing $P 1000$

Finally, the electronics enclosure is painted, giving the finished model, see Figure 9.

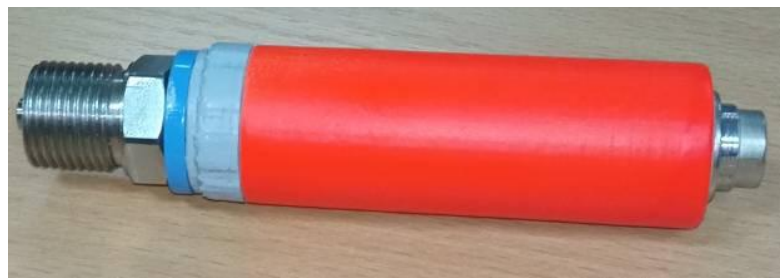

Figure 9: Realized small electronics enclosure for pressure transmitter

\section{DISCUSION AND CONCLUSION}

FDM printing allows users to be both designers and manufacturers for their own needs. Due to unrealistic expectations in the realization of models/prototypes using CT, the use of AT in terms of speed and cost of realization is increasingly resorted to.

The paper presents the algorithm and procedures for the introduction of the $6 \mathrm{R}$ strategy in sustainable enterprise development. The algorithm introduces AM in order to improve manufacturing through the fast realization of models/prototypes, quality communication with customers, and quick reaction on the market. Also, waste (and its re-use) is presented as an important resource in sustainable development. The reuse of obsolete products with redesign and remanufacturing gives a special focus on the business excellence of the enterprise. This introduces a new business practice in designing products for multiple life cycles.

AM allows the designer to choose the right technology that exactly suits his needs and meets the requirements of the prepared sample. However, the quality completely depends on the selected parameters and materials. In the realization of a small-sized electronics enclosure, care was taken to keep all the elements of the previous design and examine the cost-effectiveness of the realization of the product using AM. This is actually about the possibility of finishing, repairing, and changing the design of the existing product as well as recycling the product, all to protect the environment and minimize waste.

By detailed analysis and application of the algorithm in practice, enterprises would be able to:

- to quickly manufacture new products or models with minimal losses of energy, materials and the least possible accumulation of waste;

- to perform certain tests on the realized product regarding the connection of elements made of the same or different materials and suggestions for improvements are given in order to strengthen/stiffen the structure;

- to launch the product faster, i.e. to be able to extend the life cycle of the product with the application of new (biodegradable) materials and technologies.

\section{ACKNOWLEDGEMENT}

This work was financially supported by the Ministry of Education, Science and Technological Development of the Republic of Serbia (Grant No. 451-03-68/2020-14/200026 and Grant No. 451-0368/2020-14/200105.).

\section{REFERENCES}

Barker, S., \& King, A. (2006, May 30th). The development of a Remanufacturing Design Platform Model (RDPM): applying design platform principles to extend remanufacturing practice into new industrial sectors. In Proceedings of Life Cycle Environmental Conference. Leuven, Belgium, (pp. 399-404). CIRP.

Brackett, D., Ashcroft, I., \& Hague, R. (2011, August). Topology optimization for additive manufacturing. In Proceedings of the Solid Freeform Fabrication Symposium. Austin, TX (pp. 348-362).

Cafolla, D., Ceccarelli, M., Wang, M. F., \& Carbone, G. (2016). 3D printing for feasibility check of 
M. Vorkapić Implementation of 6R strategy in FDM printing process:

et al. Case - small electronic enclosure box

mechanism design. International Journal of

Mechanics and Control, 17(1), 3-12.

Ciubară, A., Burlea, Ș. L., Axinte, M., Cimpoeșu, R., Chicet, D. L., Manole, V., ... \& Cimpoeșu, N. (2018, May 17-18th). 3D Printer-Manufacturing of Complex Geometry Elements. In IOP Conference Series: Materials Science and Engineering. Iasi, Romania (p. 012066). IOP Publishing.

Cupar, A., Pogačar, V., \& Stjepanovič, Z. (2015). Shape verification of fused deposition modelling $3 \mathrm{D}$ prints. International Journal of Information and Computer Science, 4, 1-8. doi:10.14355/ijics.2015.04.001

Despeisse, M., \& Ford, S. (2015, September). The role of additive manufacturing in improving resource efficiency and sustainability. In IFIP International Conference on Advances in Manufacturing Management Systems. Novi Sad, Serbia (pp. 129136). Springer, Cham.

Diegel, O., Singamneni, S., Reay, S., Withell, A. (2010). Tools for sustainable product design: additive manufacturing. Journal of Sustainable Development, 3(3), 68. doi: 10.5539/jsd.v3n3p68.

Eyers, D. R., \& Potter, A. T. (2017). Industrial Additive Manufacturing: A manufacturing systems perspective. Computers in Industry, 92, 208-218. doi:10.1016/j.compind.2017.08.002

Galantucci, L. M., Lavecchia, F., \& Percoco, G. (2009). Experimental study aiming to enhance the surface finish of fused deposition modeled parts. CIRP annals, 58(1), 189-192. doi:10.1016/j.cirp.2009.03.071

Gehin, A., Zwolinski, P., \& Brissaud, D. (2008). A tool to implement sustainable end-of-life strategies in the product development phase. Journal of Cleaner Manufacturing, 16(5), 566-576. doi:10.1016/j.jclepro.2007.02.012

Hindo, B., \& Arndt, M. (2006). Everything old is new again. Business Week, 3999(1), 65-70.

Jordá-Vilaplana, A., Fombuena, V., García-García, D., Samper, M. D., \& Sánchez-Nácher, L. (2014). Surface modification of polylactic acid (PLA) by air atmospheric plasma treatment. European Polymer Journal, 58, 23-33. doi:10.1016/j.eurpolymj.2014.06.002

Junk, S., \& Schröder, W. (2016, April). Application of Sustainable Design in Additive Manufacturing of an Unmanned Aerial Vehicle. In International Conference on Sustainable Design and Manufacturin. Gold Coast, QLD, AU (pp. 375-385). Springer, Cham.

King, D. L., Babasola, A., Rozario, J., \& Pearce, J. M. (2014). Mobile open-source solar-powered 3-D printers for distributed manufacturing in off-grid communities. Challenges in Sustainability, 2(1), 1827. doi:10.12924/cis2014.02010018

Lim, S. K., Hong, E. P., Song, Y. H., Park, B. J., Choi, H. J., \& Chin, I. J. (2010). Preparation and interaction characteristics of exfoliated ABS/organoclay nanocomposite. Polymer
Engineering \& Science, 50(3), 504-512. doi: 10.1002/pen.21551

Matsumoto, M., Yang, S., Martinsen, K., \& Kainuma, Y. (2016). Trends and research challenges in remanufacturing. International Journal of Precision Engineering and Manufacturing-green Technology, 3(1), 129-142. doi: 10.1007/s40684-016-0016-4

Maxwell, D., \& Van der Vorst, R. (2003). Developing sustainable products and services. Journal of Cleaner Production, 11(8), 883-89. doi: 10.1016/S0959-6526(02)00164-6

Nannan, G. U. O. (2013). Additive manufacturing: technology, applications and research needs. Frontiers of Mechanical Engineering, 8(3), 215-243. doi:10.1007/s11465-013-0248-8

Oropallo, W., \& Piegl, L. A. (2016). Ten challenges in 3D printing. Engineering with Computers, 32(1), 135-148. doi:10.1007/s00366-015-0407-0

Otto, K. N., \& Wood, K. L. (1998). Product evolution: a reverse engineering and redesign methodology. Research in Engineering Design, 10(4), 226-243. doi:10.1007/s001639870003

Peng, T., \& Sun, W. (2017). Energy modelling for FDM 3D printing from a life cycle perspective. International Journal of Manufacturing Research, 12(1), 83-98. doi: 10.1504/IJMR.2017.083651

Qattawi, A., \& Ablat, M. A. (2017). Design consideration for additive manufacturing: fused deposition modelling. Open Journal of Applied Sciences, 7(6), 291-318. doi:10.4236/ojapps.2017.76024

Sanchez, F. A. C., Boudaoud, H., Hoppe, S., \& Camargo, M. (2017). Polymer recycling in an opensource additive manufacturing context: Mechanical issues. Additive Manufacturing, 17, 87-105. doi:10.1016/j.addma.2017.05.013

Sarkis, J. (2001). Manufacturing's role in corporate environmental sustainability-Concerns for the new millennium. International Journal of Operations \& Manufacturing Management, 21(5/6), 666-686. doi:10.1108/01443570110390390

Sossou, G., Demoly, F., Montavon, G., \& Gomes, S. (2018). An additive manufacturing oriented design approach to mechanical assemblies. Journal of Computational Design and Engineering, 5(1), 3-18. doi:10.1016/j.jcde.2017.11.005

Stephens, B., Azimi, P., El Orch, Z., \& Ramos, T. (2013). Ultrafine particle emissions from desktop 3D printers. Atmospheric Environment, 79, 334-339. doi:10.1016/j.atmosenv.2013.06.050

Van Ackere, A., Larsen, E. R., \& Morecroft, J. D. (1993). Systems thinking and business process redesign: an application to the beer game. European Management Journal, 11(4), 412-423. doi:10.1016/0263-2373(93)90005-3

Wang, W. M., Zanni, C., \& Kobbelt, L. (2016, May). Improved surface quality in $3 \mathrm{D}$ printing by optimizing the printing direction. Computer Hraphics Forum, 35(2), 59-70. doi:10.1111/cgf.12811 
Wong, K. V., \& Hernandez, A. (2012). A review of additive manufacturing. International scholarly research notices, 2012, 208760. doi: $10.5402 / 2012 / 208760$

Zeltmann, S. E., Gupta, N., Tsoutsos, N. G., Maniatakos, M., Rajendran, J., \& Karri, R. (2016). Manufacturing and security challenges in 3D printing. Jom, 68(7), 1872-1881. doi:10.1007/s11837-016-1937-7
Zivanovic, S.T., Popovic, M.D., Vorkapic, N.M., Pjevic, M.D., \& Slavkovic, N.R. (2020). An overview of Rapid Prototyping Technologies using Subtractive, Additive and Formative Processes. FME Transactions, 48(1), 246-253. doi:10.1007/s11837-016-1937-7

\title{
IMPLEMENTACIJA 6R STRATEGIJE U FDM ŠTAMPI: SLUČAJ - MALOGABARITNA KUTIJA ELEKTRONIKE
}

\begin{abstract}
U ovom radu dat je algoritam primene aditivne proizvodnje u održivom razvoju preduzeće koji obuhvata: proces pripreme proizvodnje, process realizacije proizvodnje (ili reproizvodnje), kraj procesa proizvodnje uz dodatnu obradu i postupak reciklaže optada. Implementirana je 6R strategija u realizaciji novih ili redizajnu postojećih elemenata/delova. Aditivna proizvodnja ili tehnologija FDM štampe omogućava čestu i jednostavnu modifikaciju modela na zahtev kupca, a pre ulaska modela u samu proizvodnju. Polazni materijal za izradu modela bio je polilaktična kiselina (PLA). Cilj ovog rada bio je da se prikaže postupak realizacije kutije elektronike za malogabaritni transmiter pritiska na 3D štampaču. Time se projektantu daje mogućnost da ispravi postojeće greške, modifikuje proizvod prema zahtevima krajnjih korisnika ili da isprojektuje potpuno nov proizvod (prototip). Da bi algoritam dobio pravu potvrdu, važno je da se projektuje proizvod koji omogućava: pristupačnost, laku zamenljivost, rastavljivost, mogućnost dorade i ponovne upotrebe.
\end{abstract}

Ključne reči: Algoritam, Održivi razvoj, 6R, Aditivna proizvodnja, Kutija elektronike. 